\title{
Toekomst prostaatkankerzorg door de ogen van de patiënt: de tijd is er rijp voor
}

\author{
Else J. M. Wolak ${ }^{1} \cdot$ Harm Kuipers ${ }^{1}$
}

Published online: 4 September 2017

(c) The Author(s) 2017. This article is an open access publication.

Samenvatting ProstaatKankerStichting.nl (PKS) heeft tijdens een symposium haar visie op de toekomst van de prostaatkankerzorg gepresenteerd. Een visie vanuit het perspectief van de patiënt, waarbij kwaliteitscriteria leidend zijn. Alle prostaatkankerpatiënten moeten gelijkwaardige toegang krijgen tot 'state-of-the-art'-prostaatkankerzorg; de best mogelijke behandeling met goede oncologische resultaten en zo min mogelijk bijwerkingen die de kwaliteit van leven beïnvloeden. Voor optimale prostaatkankerzorg is voldoende volume van patiënten en staf, (sub)specialisatie en een goede infrastructuur van belang. Verdergaande concentratie van de huidige prostaatkankerzorg is hiervoor nodig, uitgevoerd binnen een beperkt aantal expertcentra, eventueel aangevuld met partnerziekenhuizen. Expertcentra worden gekenmerkt door systematische samenwerking, transparant werken aan verbetering van uitkomsten, wetenschappelijk onderzoek, innovatie, samen beslissen en het meten en bespreken van patiëntervaringen.

Trefwoorden prostaatkankerzorg - patiëntenperspectief . concentratie van zorg $\cdot$ expertcentra

\section{Future of prostate cancer care through the patients' eyes: it is time}

Abstract ProstaatKankerStichting.nl (PKS) presented its vision on future prostate cancer care during a symposium. A vision from patient's perspective, based on quality criteria. All prostate cancer patients should have equal ac-

\footnotetext{
drs. Else J. M. Wolak

secretariaat@prostaatkankerstichting.nl

1 ProstaatKankerStichting.nl, Utrecht, Nederland
}

cess to 'state-of-the-art' prostate cancer care; the best possible treatment with good oncologic results and as little side effects that affect quality of life, as possible. Optimal prostate cancer care requires sufficient volume of patients and staff, (sub)specialization and adequate infrastructure. Further concentration of current prostate cancer care in a limited number of expert centers is needed, if necessary partner hospitals may join. Expert centers are characterized by systematic collaboration, transparently working towards outcome improvement, scientific research, innovation, shared decision making and assessing and discussing patient's perception.

Keywords prostate cancer care - patiënts' perspective · concentration of care $\cdot$ expert centra

\section{Introductie}

Op 12 juni 2017 heeft ProstaatKankerStichting.nl (PKS), in samenwerking met NFK (Nederlandse Federatie van Kankerpatiëntenorganisaties), tijdens een symposium voor professionals en partijen in het zorgveld, haar visie op de toekomst van de prostaatkankerzorg gepresenteerd. Een visie vanuit het perspectief van de patiënt. Een stip op de horizon naar optimale prostaatkankerzorg voor alle patiënten, waarbij kwaliteitscriteria leidend zijn.

De visie is tevens bedoeld als een uitnodiging aan partijen en professionals die betrokken zijn bij de prostaatkankerzorg in Nederland om met PKS in gesprek te gaan en samen te kijken hoe we deze visie kunnen realiseren. Bovendien willen we nadenken over hoe we de prostaatkankerzorg kunnen organiseren, optimaliseren en toekomstbestendig maken. De prostaatkankerzorg is van hoog niveau in Nederland, maar kan nog beter. 
De visie is tot stand gekomen in samenspraak met het zorgveld en sluit aan op standpunten van andere kankerpatiëntenorganisaties inzake de noodzaak voor expertzorg in de oncologie. In de visie van PKS moeten alle prostaatkankerpatiënten gelijkwaardige toegang krijgen tot 'state-ofthe-art'-prostaatkankerzorg. Daarmee wordt de best mogelijke behandeling bedoeld, met goede oncologische resultaten en met zo weinig mogelijk bijwerkingen, complicaties en negatieve gevolgen voor kwaliteit van leven, zoals impotentie, incontinentie en darmproblemen. Zorg waarbij meer aandacht is voor de complexe balans tussen overleven en optimale kwaliteit van leven. Zorg waarbij de persoonlijke waarden en wensen van de patiënt centraal staan.

\section{Waarom een visie, waarom nu?}

In Nederland krijgen elk jaar meer dan 10.000 mannen de diagnose prostaatkanker. Via onze achterban horen we geluiden die wijzen op aanzienlijke verschillen in diagnostiek en behandeling, op verschillen in indicatiestelling en op diagnostiek die soms moet worden overgedaan. Ook uit onderzoek van onder andere het Integraal Kankercentrum Nederland (IKNL; [1]) en de Santeon-ziekenhuizen blijkt dat de verleende zorg per ziekenhuis verschilt en dat niet overal optimale resultaten behaald worden, waarbij de kans op complicaties, impotentie en incontinentie verschilt. Uit de oncologische literatuur blijkt dat er een relatie is tussen volume, behandeling, oncologische uitkomsten en kwaliteit van leven, en wordt gewezen op het belang van specialisatie [2-4]. Cijfers van de Martini-Klinik in Hamburg, waar veel radicale prostatectomieën worden gedaan door een gespecialiseerd team, ondersteunen het belang van (sub)specialisatie en volume/concentratie [5].

Het zorgveld zelf is ook in beweging. In Nederland bestaan verschillende initiatieven om te komen tot kwaliteitsverbetering en tot betere prostaatkankerzorg, door krachten te bundelen, door meer nadruk te leggen op specialisatie en concentratie en door uitkomsten inzichtelijk te maken en te bespreken. Ook in andere Europese landen zijn er bewegingen in de richting van gespecialiseerde centra voor prostaatkankerzorg. Verder zijn er nieuwe ontwikkelingen inzake diagnostiek en behandeling van (uitgezaaide) prostaatkanker, zoals verbeterde diagnostiek door middel van MRI-geleide biopten en andere effectieve systemische therapieën naast hormoontherapie.

\section{Enkele uitgangspunten voor de toekomstvisie van PKS}

Voor optimale prostaatkankerzorg is voldoende volume van patiënten en staf, (sub)specialisatie en een goede infrastruc- tuur van belang. Dit vraagt om vergaande concentratie van de huidige prostaatkankerzorg, met aandacht voor regionale spreiding ten behoeve van een goede bereikbaarheid voor de patiënt. PKS bepaalt niet wie zorg mag leveren of hoeveel ziekenhuizen zorg mogen leveren, maar vindt dat prostaatkankerzorg aan de hoogste kwaliteitseisen moet voldoen.

\section{Naar expertcentra toewerken}

PKS vindt daarom dat diagnostiek, behandeling en nazorg alleen uitgevoerd mogen worden door een multidisciplinair team van gesubspecialiseerde professionals die volledig toegewijd zijn (dedicated) aan prostaatkanker. In deze teams wordt systematisch samengewerkt, werkt men transparant aan verbetering van uitkomsten en staan wetenschappelijk onderzoek en innovatie centraal. De cultuur kenmerkt zich door kwaliteit, samenwerking, innovatie en compassie. Patiëntparticipatie (samen beslissen, het meten en bespreken van patiëntervaringen) zijn een standaardonderdeel van de zorg.

Een expertcentrum voert de regie, eventueel aangevuld met partnerziekenhuizen. PKS is overtuigd van de noodzaak van concentratie van prostaatkankerzorg naar een beperkt aantal expertcentra met regiefunctie, eventueel aangevuld met partnerziekenhuizen, geografisch verspreid over Nederland. Dit gaat verder dan een enkele focus op netwerkvorming. Idealiter vinden alle behandelingen plaats onder één dak, maar in de partnerziekenhuizen kunnen onderdelen van de zorg worden uitgevoerd op basis van shared-care-afspraken. Een beperkt aantal expertcentra maakt het mogelijk om niet alleen voldoende volume van medische handelingen te bereiken, maar vooral ook om de noodzakelijke expertise, infrastructuur en cultuur te organiseren. Welk model ook wordt gekozen, een dergelijk model zal altijd nader moeten worden uitgewerkt door de betrokken beroeps- en patiëntenvertegenwoordigers, in samenspraak met betrokken ziekenhuizen en zorgverzekeraars.

Expertcentra maken schriftelijke afspraken over taken en verantwoordelijkheden van het expertteam, om te komen tot samenwerking in netwerkverband tussen de eerste, tweede en derde lijn, bijvoorbeeld ten aanzien van verwijzing en taakverdeling met de eerste lijn in, met name, de diagnostische en palliatieve fase. Van expertcentra en de (eventueel) daaraan gelieerde partnerziekenhuizen wordt verwacht dat zij niet alleen aan de SONCOS-minimumnormen voor prostaatcarcinoom voldoen, maar ook aan de door PKS opgestelde criteria. Het expertcentrum stelt dezelfde eisen aan partnerziekenhuizen inzake specialisatie, infrastructuur en participatie in onderzoek. 


\section{Kenmerken van een expertcentrum}

- Een expertcentrum biedt de hele prostaatkankerzorg, van diagnostiek tot behandeling, nazorg en palliatie.

- Een expertcentrum biedt deze zorg in één gespecialiseerd (dedicated), multidisciplinair prostaatkankerteam, dat 24/7 'state-of-the-art'-zorg op het hoogste niveau levert. Onder de regie van dit expertcentrum worden alle patiënten met prostaatkanker gediagnosticeerd en behandeld. Het team bestaat uit minimaal twee in prostaatkanker ge(sub)specialiseerde urologen, medisch oncologen, radiotherapeuten, radiologen, pathologen en oncologieverpleegkundigen en minimaal één nucleair geneeskundige.

- Een expertcentrum biedt alle mogelijkheden voor diagnostiek en behandeling naar de laatste stand van de wetenschap, zoals MRI-geleide biopten, beschikt over een team dat ervaring heeft met laparoscopische en open ingrepen (w.o. robotgestuurd), en over alle vormen van radiotherapie en van toepassing zijnde vormen van systemische therapie.

- Een expertcentrum heeft een multidisciplinaire polikliniek en multidisciplinair overleg (MDO).

- Een expertcentrum koppelt hoogwaardige multidisciplinaire zorg aan innovatief wetenschappelijk onderzoek naar prostaatkanker (bijv. DNA-diagnostiek).

- Een expertcentrum informeert en faciliteert de patiënt, zodat sprake kan zijn van gewogen keuzes en gezamenlijke besluitvorming, en patiënten de regie over hun eigen zorgproces kunnen nemen (bijv. de inzet van keuzehulpen, een digitaal patiëntenportaal).

- Een expertcentrum levert een casemanager die voor de patiënt de spin in het web is in het zorgnetwerk.

- Een expertcentrum meet, registreert en is transparant over aantallen en uitkomsten van diagnostiek en behandeling, en patiëntervaringen (PROM's en PREM's). Deze gegevens gebruikt men voor evaluatie, kwaliteitsbewaking en -verbetering.

- Een expertcentrum draagt bij aan ontwikkeling van specifieke kennis door actieve deelname aan studies en levert wetenschappelijke publicaties.

PKS vindt dat een expertcentrum minstens 1000 nieuwe patiënten per jaar moet zien en minimaal 250 radicale prostatectomieën (RP'en) per jaar dient uit te voeren. Hierbij wordt uitgegaan van minimaal 50 RP'en per operateur per jaar; het streven is $100 \mathrm{RP}$ 'en per operateur per jaar, met een leercurve van ten minste 250 RP'en in een trainingscontext. Aantallen zijn niet alleen belangrijk voor chirurgie, maar ook voor diagnostiek en andere behandelingen.

Goede diagnostiek moet de basis vormen van het persoonlijk behandeladvies, op grond waarvan de patiënt zijn afwegingen en keuzes kan maken; een behandeladvies dat breed gewogen is in het MDO en onafhankelijk is van het behandelaanbod.

\section{Tot slot}

PKS blijft graag bij het proces van optimaliseren van prostaatkankerzorg betrokken en wil dat haar visie meegenomen wordt bij ontwikkelingen en initiatieven in het prostaatkankerzorgveld. Hiertoe nodigen we het veld uit.

Open Access This article is distributed under the terms of the Creative Commons Attribution 4.0 International License (http:// creativecommons.org/licenses/by/4.0/), which permits unrestricted use, distribution, and reproduction in any medium, provided you give appropriate credit to the original author(s) and the source, provide a link to the Creative Commons license, and indicate if changes were made.

\section{Literatuur}

1. Siesling S, Sonke G, Raaf A de, et al. Kankerzorg in beeld. Utercht: IKNL; 2014.

2. Barocas DA, Mitchell R, Chang SS, et al. Impact of surgeaon and hospital volume on outcomes of radical prostatectomy. Urol Oncol. 2010;28:243-50.

3. Trinh QD, Bjarell A, Freedland SJ, et al. A systematic review of the volume-outcome relationship for radical prostatectomy. Eur Assoc Urol. 2013;64:786-98.

4. Steinsvik EAS, Axcrona K, Angelsen A, et al. Does a surgeon's radical prostatectomy volume predict the risk of positive surgical margins and urinary incontinence at one-year follow-up? Findings from a prospective national study. Scand J Urol. 2013;47:92-100.

5. Porter ME, Deerberg-Wittram J, Marks C. Martini Klinik: prostate cancer care. Harvard: Harvard Business School. 2014. https:// www.martini-klinik.de/en/results/. Geraadpleegd op: 27 jul 2016.

drs. Else J.M. Wolak beleidsmedewerker ProstaatKankerStichting.nl prof. dr. Harm Kuipers lid Kwaliteitscommissie ProstaatKankerStichting.nl 